\title{
Footloose and duty-free? Reflections on European Union - Anti-Dumping Measures on Certain Footwear from China
}

\author{
JEFFREY L. DUNOFF* \\ Temple University \\ MICHAEL O. MOORE** \\ George Washington University
}

\begin{abstract}
European Union (EU) anti-dumping duties imposed on Chinese leather footwear imports led to a challenge before the WTO Dispute Settlement body. The Panel ruled that the EU's presumption that Chinese exporters are subject to economy-wide non-market-economy anti-dumping duties was inconsistent with WTO obligations. The EU declined to appeal this outcome and subsequently changed its anti-dumping regulation in response. This dispute also illustrates the rapidly changing structure of global manufacturing and how these changes can scramble the traditional political economy of import restrictions. In addition, the case highlights how EU members' positions on trade remedy actions can depend importantly on national production patterns and firms' responses to economic pressures from globalization and the further development of global supply chains.
\end{abstract}

\section{Introduction}

The European Union-Anti-Dumping Measures on Certain Footwear from China dispute $(E U-F o o t w e a r)^{1}$ involves a challenge to European Union (EU) antidumping duties imposed on Chinese leather footwear imports. Many of the dispute's key legal issues are rather technical. But the case vividly illustrates many economic, political, and doctrinal complexities raised by recent trends in economic globalization.

EU-Footwear highlights the rapidly changing nature of global manufacturing, especially fragmented global supply chains and the physical separation between

\footnotetext{
* Email: jeffrey.dunoff@temple.edu.

**Email: mom@gwu.edu.

The authors would like to thank Andrea Mastromatteo, Edwin Vermulst, Jappe Eckhardt and other participants at the European University Institute's conference on WTO case law for thoughtful comments on earlier drafts. All errors are our own.

1 Panel Report, European Union-Anti-Dumping Measures on Certain Footwear from China, WT/DS405/R, adopted 22 February 2012.
} 
headquarter operations (administration, marketing, etc.) and assembly locations. These dramatic manufacturing changes raise questions about whether current anti-dumping rules, drafted in a very different economic context, are well suited to current realities.

This dispute challenges the conventional political economy wisdom that importcompeting firms have the incentive to mobilize and the ability to influence trade policy in ways that other actors lack. The threat of anti-dumping duties sparked a sustained and effective counter-response by import-dependent European firms. The decision to impose duties was politically contentious, and the duties imposed were lower, and for a shorter period of time, than is normally the case. The dispute thus illustrates how 'off-shoring' scrambles the traditional mix of domestic versus foreign interests found in most disputes over import restrictions, and raises questions concerning whether we are entering a new era in terms of the political economy of contingent protection.

Finally, the dispute highlights the 'power of procedure'. EU firms seeking protection would have been better served by a safeguard action. However, safeguard procedural rules incentivized the industry to pursue anti-dumping duties instead. The anti-dumping orders, in turn, sparked a WTO challenge that turned largely on whether relevant EU regulations improperly allocated a burden of proof irrelevant to safeguards but central to anti-dumping. While procedural rules like burdens of proof might seem far removed from the great issues of trade policy, EUFootwear reminds us that they often drive even the most politically contentious disputes.

To explore the issues raised by the Footwear dispute, this paper proceeds in three parts. Section 1 reviews the dispute's legal, economic, and political background. Section 2 examines the key legal issues addressed by the Panel. Section 3 explores some of the Footwear dispute's most important implications. A brief conclusion follows.

\section{Understanding the Footwear dispute}

The EU-Footwear dispute involves a highly complex legal and factual context. We begin with a summary chronology of the case (see Table 1 ) and provide more detail below.

European quotas against Chinese footwear imports, which had been part of a global system of quotas on clothing and apparel, expired in January 2005. Later that year, EU footwear producers filed an anti-dumping petition claiming that dumped Chinese imports were causing injury to the EU industry. The European Commission ('Commission') recommended, and the European Council of Ministers ('Council') approved, the imposition of anti-dumping duties in October 2006. In May 2010, a WTO Panel was established to consider various aspects of the EU anti-dumping decisions. The panel report, finding the $\mathrm{EU}$ in violation of WTO commitments, was circulated in October 2011. In June 2012, the 
Table 1. EU-Footwear timeline

\begin{tabular}{ll}
\hline \hline Date & Event \\
\hline January 2005 & Expiration of Chinese footwear quotas \\
July 2005 & Anti-dumping investigation initiated \\
March 2006 & Provisional duties \\
October 2006 & Definitive duties for two years (normally five years) \\
December 2009 & Expiry review; duties extended for fifteen months (until April 2011) \\
May 2010 & WTO panel established at Chinese request \\
April 2011 & EU terminates anti-dumping duties on footwear \\
October 2011 & Panel report circulated \\
February 2012 & Panel report adopted by Dispute Settlement Body \\
June 2012 & EU reform of 'individual treatment' provisions \\
& \\
\hline
\end{tabular}

EU reformed its anti-dumping regulations in light of the panel report in Footwear and the Appellate Body report in EU-Fasteners ${ }^{2}$, which addressed similar issues.

\subsection{Legal background: a brief overview of the EU's trade defense system}

EU-Footwear arises against the backdrop of the EU's trade remedies regime.

\section{(1) EU Anti-dumping rules}

Under the EU's Anti-Dumping Regulation (ADR), ${ }^{3}$ investigations are typically triggered by individual firm or industry group allegations of injurious dumped imports, although the Commission can self-initiate. The Commission examines whether: (i) the product is dumped, i.e., whether firms' export prices to the EU are less than 'normal' value; (ii) the imports cause material injury to a Community industry producing the like product; and (iii) there is a causal link between the dumped imports and injury. In addition, the Commission must determine that antidumping measures would not be contrary to Community interest, i.e. 'all the various interests taken as a whole, including the interests of the domestic industry and users and consumers'. ${ }^{4}$ The Council can subsequently decide, by simple majority vote, to accept the Commission's recommendation to impose definitive measures, which can last up to five years. An anti-dumping order is subject to an 'expiry review' after five years to determine whether revoking the duties would cause a recurrence of dumping and material injury.

2 Appellate Body Report, European Union-Definitive Anti-Dumping Measures on Certain Iron or Steel Fasteners from China, WT/DS397/AB/R, adopted 28 July 2012

3 EU (2009) (hereinafter ADR).

4 Ibid, Article 21 (1). The ADR provides that measures will not be imposed if the authorities 'can clearly conclude' that the measures are not in the Community's interest (ibid.) and the Commission has interpreted this to mean that '[measures] would only be considered as not in the interest of the Community, if they had disproportionate effects on the [negatively affected] parties'. EU (2006b), recital 279. 
The ADR also requires the Commission to consult with the Anti-Dumping Advisory Committee, which consists of representatives of each member state. Consultations address issues such as whether to initiate proceedings, whether measures should be imposed, and whether measures should be amended. The Committee's advice does not bind the Commission; hence the Commission may open an investigation and impose provisional measures even if a majority of EU member states are opposed. Nevertheless, the consultations permit the Commission to receive feedback on proposed actions, and no doubt inform the Commission's final recommendations.

\section{(2) The ADR's treatment of non-market economies}

The ADR contains special rules for calculating 'normal value' for non-market economies (NMEs). The ADR provides that normal value for NME exports 'shall be determined on the basis of the price or constructed value in a market economy third country, or the price from such a third country to other countries ... or where those are not possible, on any other reasonable basis' (ADR Article 2(7)(a)). This is in contrast to 'market-economy' investigations where normal value is based typically on economic conditions within the exporting country.

The Commission, however, may use standard market economy techniques under some circumstances for exports from China (as well as from Kazakhstan and any NME country that is a member of the WTO at the date of the initiation of the investigation). In particular, '[if] market economy conditions prevail for this producer or producers in respect of the manufacture and sale of the like product concerned (emphasis added)', then normal value for an individual Chinese exporter shall be determined under the rules generally applicable to products from market economies. ${ }^{5}$ When this so-called 'market economy test' (MET) is not satisfied, then normal value is calculated according to the rules set out under NME rules of Article 2(7)(a).

ADR Article 9(5) is the second relevant NME rule and a central aspect of the Footwear dispute. The Commission may choose not to specify individual duties for each supplier: (1) when it is impracticable to name each supplier, or (2) when Article 2(7)(a) of the ADR applies - that is, where normal value is determined under

5 The relevant criteria, referred to as the 'market economy test', require evidence that:

(a) decisions of firms regarding prices, costs and inputs, including for instance raw materials, cost of technology and labour, output, sales, and investment, are made in response to market signals reflecting supply and demand, and without significant State interference in this regard, and costs of major inputs substantially reflect market values;

(b) firms have one clear set of basic accounting records which are independently audited in line with international accounting standards and are applied for all purposes;

(c) the production costs and financial situation of firms are not subject to significant distortions carried over from the former non-market economy system, in particular in relation to depreciation of assets, other write-offs, barter trade and payment via compensation of debts;

(d) the firms concerned are subject to bankruptcy and property laws which guarantee legal certainty and stability for the operation of firms, and

(e) exchange rate conversions are carried out at the market rate. 
Figure 1. Share of AD cases against NMEs in total AD cases, per year of initiation

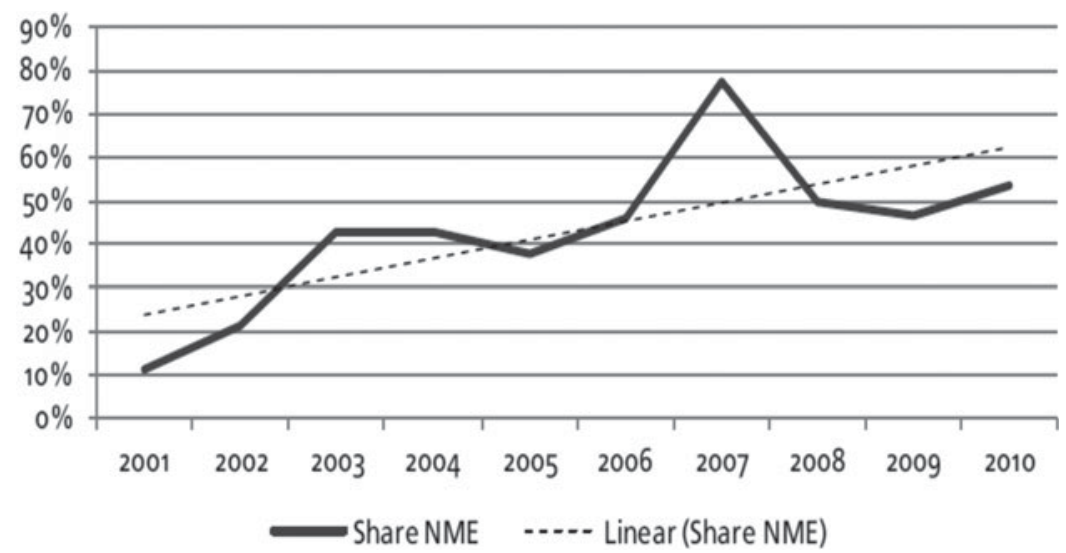

Source: Reproduced from BKP (2012).

NME rules. In these cases, a single 'countrywide' duty rate will be specified, rather than an individual duty rate for 'each supplier'.

Article 9(5) further provides that even when normal value is determined using NME rules, producers can seek the calculation of individual duty rates (so-called 'individual treatment' or 'IT'). To receive an individual duty rate, the producer must satisfy a number of enumerated criteria, including export requirements. Producers that satisfy these conditions will receive an individual duty rate; producers that fail to satisfy the IT test will be subject to the countrywide duty rate.

The practical effect of these NME rules is extremely significant. The number of EU anti-dumping investigations cases involving NMEs is large and trending upward (see Figure 1).

From 2000 to $2010,48 \%$ of the 116 AD cases in the EU were against NMEs. China's role has been particularly notable in this trend. Between 1995 and 2011, $77 \%$ of all NME cases involved Chinese imports (see Figure 2).

NME producers have had difficulty establishing that they operate under market conditions. Between 2005 and 2010, some 141 producers submitted MET applications but only 29 firms (21\%) were granted MET. Of these applications, 129 were from Chinese firms, and $27(21 \%)$ of these requests were granted (see Table 2). In contrast, producers apply for individual treatment (IT) less frequently, but with greater success. Between 2005 and 2010, 113 Chinese firms sought IT, and 64 (57\%) of these requests were granted (BKP, 2012).

Finally, the practical difference between being treated under the rules for market economies and being treated as an NME is quite substantial. Table 3 summarizes the differential effect on firms that receive MET treatment and those that do not. The average anti-dumping duties for firms that received MET was $6.9 \%$, including 
Table 2. Success rate of MET applications in AD cases initiated 2005-2010

\begin{tabular}{lrc}
\hline \hline Exporting country & $\begin{array}{l}\text { No. of companies whose MET } \\
\text { applications were investigated }\end{array}$ & $\begin{array}{l}\text { No. of companies } \\
\text { granted MET }\end{array}$ \\
\hline Armenia & 1 & 0 \\
China & 129 & 27 \\
Kazakhstan & 1 & 1 \\
Moldova & 1 & 0 \\
Ukraine & 1 & 1 \\
Vietnam & 8 & 0 \\
Total & 141 & 29 \\
\hline \hline
\end{tabular}

Source: Reproduced from BKP (2012).

Figure 2. EU anti-dumping initiations against non-market economies (1995-2011)

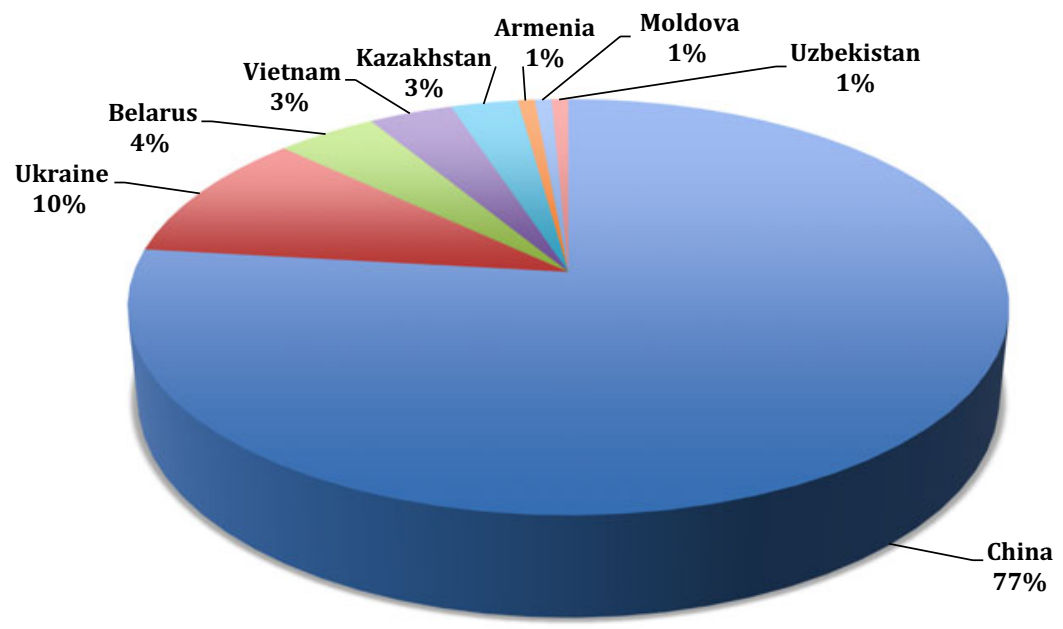

Total number of initaitions: 138

Source: Bown (2012)

four instances where the responding firms were found to not dump (i.e. a dumping margin of zero). In sharp contrast, the countrywide duty was $44.2 \%$ (not including two specific duties); thus MET firms on average face duties only $17.5 \%$ as high as those that do not. Chinese interests in pursuing tightened disciplines on the use of MET standards are therefore quite clear.

\section{(3) The EU's safeguards regime}

In Section 3, we explore whether the Footwear dispute involves circumstances that are more suggestive of a potential safeguard action than an anti-dumping 
Table 3. Effect of market economy treatment (MET) by EU

\begin{tabular}{lcccc}
\hline \hline Year & $\begin{array}{l}\text { Number of } \\
\text { companies } \\
\text { granted MET }\end{array}$ & $\begin{array}{l}\text { Simple average duties } \\
\text { of companies granted } \\
\text { MET }(\%)\end{array}$ & $\begin{array}{l}\text { 'Country-wide' } \\
\text { all-others duty } \\
\text { rate }(\%)\end{array}$ & $\begin{array}{l}\text { Average MET duty } \\
\text { as percentage of } \\
\text { country-wide rate }\end{array}$ \\
\hline 2005 & 7 & 8.8 & 28.8 & 30.6 \\
2005 & 1 & 17.0 & 63.5 & 26.8 \\
2006 & 1 & 0.0 & 189.4 EUR/ton & 0.0 \\
2006 & 2 & 0.0 & 38.1 & 0.0 \\
2006 & 2 & 2.9 & 29.6 & 9.8 \\
2006 & 1 & 12.3 & 71.8 & 17.1 \\
2006 & 2 & 15.6 & 31.2 & 50.0 \\
2006 & 2 & 12.2 & 77.6 & 15.7 \\
2007 & 2 & 7.5 & 42.7 & 0.0 \\
2008 & 1 & 0.0 & $549 \mathrm{EUR} / \mathrm{ton}$ & 7.1 \\
2009 & 1 & 5.6 & 79.2 & 0.0 \\
2009 & 1 & 0.0 & 9.8 & 52.9 \\
2009 & 1 & 7.3 & 13.8 & 17.5 \\
Average & 1 & 6.9 & $44.2 *$ & \\
\hline \hline
\end{tabular}

Note: *Average does not include specific duty rates.

Source: Adapted from BKP (2012).

investigation. Thus, we provide a very short overview of the EU's safeguards scheme. EU law provides for two types of safeguards: (1) global safeguards, which are imposed on a most-favored-nation basis; and (2) China-specific safeguards, which restrict only Chinese products. In either case, only a member state or the Commission may initiate an investigation. This is quite different from an antidumping investigation where the EU industry itself may initiate the process. In other words, decisions to impose safeguards are inherently more political in nature since government authorities must start the process.

EU law authorizes global safeguards where a product is imported into the EU in such increased quantities so as to cause, or threaten to cause, serious injury to Community producers of like or directly competing products. Thus, unlike in antidumping actions, there is no need to show that foreign products are priced 'unfairly'. The objective of a global safeguard 'is to give the industry a temporary breathing space to make necessary adjustments - [global] safeguards always come with an obligation to restructure'. ${ }^{6}$

The Commission conducts the serious injury investigation. If the Commission rules affirmatively, a qualified majority of the Council may reaffirm, reject, or

6 European Commission, 'Safeguards', available at http://ec.europa.eu/trade/policy/accessing-markets/ trade-defence/actions-against-imports-into-the-eu/safeguards/ (last visited 14 May 2013). 
change the Commission's recommendation. In contrast, anti-dumping orders require only a simple majority of the Council of Ministers.

Global safeguard measures are limited to the time necessary to prevent or remedy serious injury and to facilitate Community producer's adjustment. Safeguard measures are normally imposed for a maximum period of four years, and can be extended for a total of eight years following additional investigation. The WTO Safeguards Agreement stipulates that any action longer than four years requires compensation to foreign suppliers.

EU law allowed for China-specific safeguards until the end of 2013. Under China's Accession Protocol, WTO Members could impose safeguards on Chinese exports only if those products caused 'market disruption' to a domestic industry producing a like product.

The relevant EU regulations for China-specific safeguards defined market disruption as 'material injury' so that the injury criterion in China-specific safeguard cases was essentially identical to that of an anti-dumping action. If the Commission determined that Chinese exports caused or threatened to cause material injury, then restrictions could be placed on Chinese imports with a Council qualified majority. Unlike global safeguards, there was no requirement that compensation be provided, although China's Accession Protocol states that China 'has the right' to suspend the application of substantially equivalent General Agreement on Tariffs and Trade (GATT) concessions or obligations if the safeguard is in effect for an extended period.

Table 4 summarizes some of the core aspects of and key differences among the different trade defense mechanisms. The most important differences include which actors may initiate a petition, the necessity of demonstrating 'unfair' pricing, the level of political support required to impose duties, and the time frame and the breadth of the restrictions. These differences make clear that the choice of instrument will be critical to obtaining import barriers as well as the effectiveness of the restrictions. In addition, the choice of instruments determines the type of complaint that the EU might face in a WTO dispute.

\subsection{Economic background: the changing global market for footwear}

The European footwear industry has come under increasing pressure from international competitors, particularly from developing countries. A handful of EU member states that have been traditional producers in recent decades have felt these pressures most acutely. Footwear firm responses have been heterogeneous, with many larger firms 'off-shoring' their assembly operations, an option that is much more difficult for small, less-productive firms. These factors have helped determine firm and national attitudes towards trade restrictions.

The pressures on the European footwear industry are typical of the global economic realities in the clothing and textiles sectors. These are generally labor-intensive sectors, where wage costs can play an important role in determining the production location. For decades, developed nations insisted on a global system 
Table 4. Summary of key EU trade defense instruments

\begin{tabular}{|c|c|c|c|c|c|c|c|c|}
\hline $\begin{array}{l}\text { Trade } \\
\text { measure }\end{array}$ & $\begin{array}{l}\text { Number of } \\
\text { initiations } \\
(1995-2011)\end{array}$ & Initiating body & $\begin{array}{l}\text { Injury } \\
\text { investigation }\end{array}$ & $\begin{array}{l}\text { Unfair price } \\
\text { investigation }\end{array}$ & $\begin{array}{l}\text { Council of } \\
\text { Ministers } \\
\text { role in final } \\
\text { decision }\end{array}$ & Application & Duration & Justification \\
\hline Anti-dumping & 433 & $\begin{array}{l}\text { Community } \\
\text { industry with } \\
\text { majority } \\
\text { support }\end{array}$ & $\begin{array}{l}\text { Material } \\
\text { injury }\end{array}$ & $\begin{array}{c}\text { Presence of } \\
\text { dumping }\end{array}$ & $\begin{array}{l}\text { Simple } \\
\text { majority } \\
\text { support }\end{array}$ & $\begin{array}{l}\text { Specific to } \\
\text { individual } \\
\text { firms or } \\
\text { countries }\end{array}$ & $\begin{array}{l}\text { Expiry review within five } \\
\text { years; possible five year } \\
\text { extension }\end{array}$ & $\begin{array}{l}\text { Reaction to } \\
\text { 'unfair' pricing }\end{array}$ \\
\hline $\begin{array}{l}\text { Global } \\
\text { safeguards }\end{array}$ & 5 & $\begin{array}{l}\text { Commission or } \\
\text { Member State }\end{array}$ & $\begin{array}{r}\text { Serious } \\
\text { injury }\end{array}$ & NA & $\begin{array}{l}\text { Qualified } \\
\text { majority } \\
\text { support }\end{array}$ & $\begin{array}{l}\text { Applied on all } \\
\text { import } \\
\text { sources }\end{array}$ & $\begin{array}{l}\text { Four year limit, which } \\
\text { can be extended for an } \\
\text { additional four years; } \\
\text { compensation if longer } \\
\text { than four years }\end{array}$ & $\begin{array}{l}\text { Temporary } \\
\text { protection while } \\
\text { domestic industry } \\
\text { adjusts to new } \\
\text { competition }\end{array}$ \\
\hline $\begin{array}{l}\text { China-specific } \\
\text { safeguard }\end{array}$ & 1 & $\begin{array}{l}\text { Commission or } \\
\text { Member State }\end{array}$ & $\begin{array}{l}\text { Material } \\
\text { injury }\end{array}$ & NA & $\begin{array}{l}\text { Qualified } \\
\text { majority } \\
\text { support }\end{array}$ & $\begin{array}{l}\text { Applied only } \\
\text { on Chinese } \\
\text { imports }\end{array}$ & $\begin{array}{l}\text { No maximum duration; } \\
\text { China can suspend } \\
\text { substantially equivalent } \\
\text { concessions under } \\
\text { certain conditions }\end{array}$ & $\begin{array}{l}\text { Reaction to } \\
\text { possible China } \\
\text {-specific surges } \\
\text { (expired in 2013) }\end{array}$ \\
\hline
\end{tabular}

Sources: OJ references for all; Bown (2012). 
Table 5. Covered products import patterns

\begin{tabular}{|c|c|c|c|c|c|c|c|}
\hline & 2001 & 2002 & 2003 & 2004 & 2005 & 2006 & 2007 \\
\hline \multicolumn{8}{|l|}{ China } \\
\hline Volume (thousand pairs) & 15,571 & 14,616 & 25,810 & 30,662 & 183,568 & 157,560 & 123,016 \\
\hline Market share in EU & $2.2 \%$ & $2.3 \%$ & $3.9 \%$ & $4.4 \%$ & $22.9 \%$ & $21.6 \%$ & $17.8 \%$ \\
\hline \multicolumn{8}{|l|}{ Vietnam } \\
\hline Volume (thousand pairs) & 51,414 & 59,898 & 83,334 & 103,177 & 100,619 & 79,427 & 62,503 \\
\hline Market share in EU & $7.2 \%$ & $9.3 \%$ & $12.4 \%$ & $14.0 \%$ & $12.6 \%$ & $11.0 \%$ & $9.1 \%$ \\
\hline
\end{tabular}

Sources: EU (2006b) and Council Implementing Regulation (EU) No. 1294/2009.

of quotas on textiles and apparel (variously called the 'Multi-fiber Agreement' and 'Agreement on Textiles and Clothing' (ATC)) that limited developing country exports of these products to high-income markets. A key concession in the successful completion of the Uruguay Round was the phase-out of these global ATC quotas at the end of 2004.

The phase-out of the quotas significantly affected the European footwear market. UN Comtrade data shows that EU-27 footwear imports rose over $25 \%$ in the year that the quotas were removed (€4.6 billion in 2004 to $€ 5.8$ billion in 2005). Chinese footwear exports to the EU rose from $€ 0.84$ billion in 2004 to $€ 2.1$ billion in 2005 or $150 \%$ increase in value. In fact, the increase in the value of total EU imports from 2004 to 2005 of $€ 1.17$ billion almost matches the increase in Chinese footwear sales of $€ 1.25$ billion. Broadly speaking, Chinese footwear occupied the lower end of the market place; the Commission reports an average Chinese sales price of $€ 7.5$ compared to $€ 19.8$ in 2004 for a sample of EU footwear producers. ${ }^{7}$ Thus, the data on exports understate the pressure since these data reflect aggregate value rather than quantity of shoe pairs.

EU-Footwear however deals with a narrower product category - footwear with leather uppers. There was an even more dramatic increase in this category: the quantity of Chinese imports sextupled from 30,662 pairs in 2004 to 183,568 pairs in 2005 (when the quota was eliminated) while China's market share in EU countries rose from $4.4 \%$ of total imports in 2004 to $22.9 \%$ in 2005 (see Table 5). Any analysis of EU-Footwear should also take into account imports from Vietnam, which faced a contemporaneous anti-dumping action. Vietnamese exports did not experience the dramatic growth in the broad footwear category. Table 5 shows that the covered Vietnamese products in the anti-dumping action actually fell from 103,177 pairs in 2004 to 100,619 pairs in 2005, with an EU import market share of around $14 \%$. 
Figure 3. EU footwear production (2006)

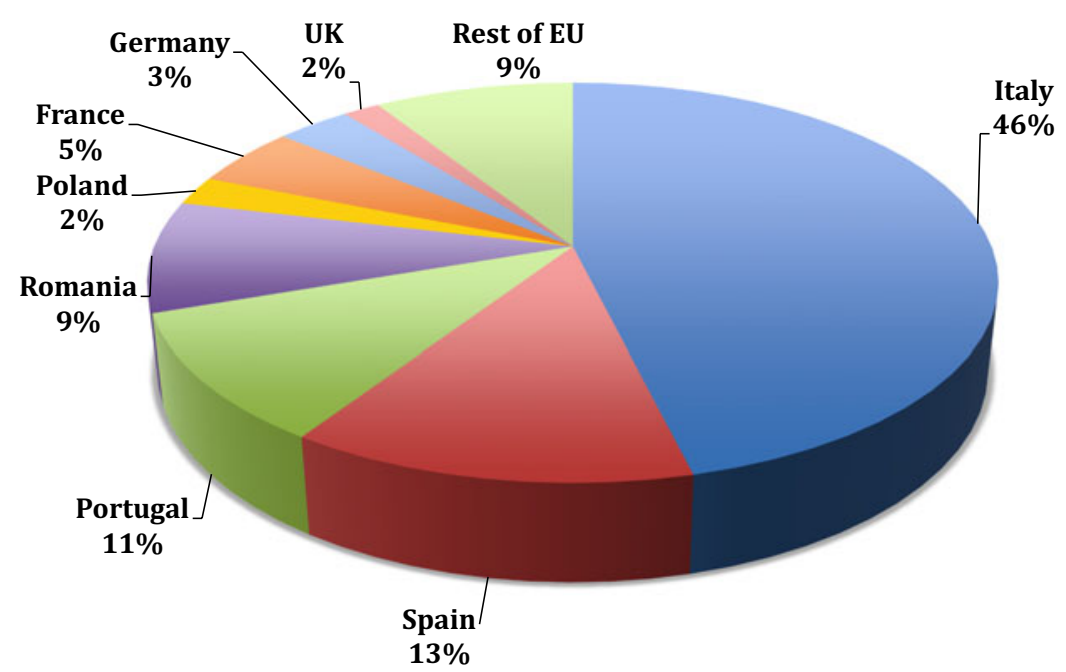

Note: Authors' calculations based on Eurostat, http://epp.eurostat.ec.europa.eu/portal/page/portal/ prodcom/data/tables_excel.

EU footwear production is concentrated in a relatively small number of member states, especially in Mediterranean countries and some central European states. Italy's footwear industry continues to be important, with particular focus on highend leather shoes. Figure 3 shows production patterns in 2006 (the year the footwear anti-dumping duty came into force) for three products: men's, women's, and children's leather 'town shoes' (Prodcom categories: 15201351/52/53). ${ }^{8}$ Italian firms represent $46 \%$ of the total EU-27 value, followed by Spain $(13 \%)$ and Portugal $(11 \%)$. These three countries, reportedly the main proponents of import restrictions, manufactured just below $70 \%$ of EU production in the year that the anti-dumping investigation was initiated. Other member countries (for example Britain and Germany) produce less than 3\% (each) of these goods and Sweden does not produce them at all.

Some EU nations have important footwear firms that tend to offshore much of their production. These firms are generally large, highly productive companies with global supply chains and a wide variety of end markets. These companies typically undertake research and development and other high-value added activities in developed countries (including EU members) while production is offshored to countries like China and Vietnam. This fragmentation of corporate operations

8 Compiled by the authors with data from Eurostat, http://epp.eurostat.ec.europa.eu/portal/page/ portal/prodcom/data/tables_excel. 
Table 6. Adidas global activities (2012)

\begin{tabular}{lccc}
\hline \hline Region & Wholesale net sales & Footwear production & Employees by region \\
\hline Europe & $40 \%$ & $1 \%$ & $54 \%$ \\
Western Europe & $34 \%$ & & $24 \%$ \\
European Emerging Markets & $6 \%$ & $96 \%$ & $30 \%$ \\
Asia & $30 \%$ & $33 \%$ & $14 \%$ \\
China & $14 \%$ & $63 \%$ & $4 \%$ \\
Other Asian Markets & $16 \%$ & $31 \%$ & $10 \%$ \\
Vietnam & & $26 \%$ & \\
Indonesia & $30 \%$ & $3 \%$ & $32 \%$ \\
Americas & $18 \%$ & & $25 \%$ \\
North America & $12 \%$ & & $7 \%$ \\
Latin America & & & \\
\hline \hline
\end{tabular}

Note: Production levels are for: adidas, Reebok, and adidas Golf.

Source: adidas Group (2012).

means that multinational footwear companies have incentives to oppose footwear import restrictions.

Adidas is a useful example. Adidas AG, founded Germany 1948, had global net sales of almost $€ 15$ billion in 2012, with $40 \%$ of sales in Europe (see Table 6). ${ }^{9}$ Production is almost non-existent in Europe with three European plants (one each in Germany, Sweden, and Finland) and four in North America (one in the USA and three in Canada). Moreover, almost $100 \%$ of adidas production is outsourced, almost all of which comes from Asia (33\% from China, 31\% from Vietnam, and $26 \%$ from Indonesia). The firm's employees, however, are concentrated in Europe $(54 \%)$, many of whom engage in high value-added activities such as marketing, research and development, and other headquarter type operations. Not surprisingly, adidas opposed import restrictions, including through the Federation of European Sporting Goods Industry (FESI) (Eckhardt, 2011).

These patterns are similar to what one might expect from recent studies on the effects of heterogeneous firms in international trade: large, more productive firms have an international presence and those with the highest productivity establish foreign affiliates. ${ }^{10}$ Many firms supporting the imposition of antidumping duties were based in Italy, Spain, and Portugal and - at the time of the expiry review-Poland and Romania. These were relatively small firms that typically had European-centric production operations and sales. Their cost

9 All detailed adidas AG information is obtained from its 2012 Corporate Annual Report, see adidas Group (2012).

10 See Melitz (2003) and Helpman et al. (2004). 
structures were relatively high compared to those of Chinese producers/exporters (and European multinationals).

The diverse production patterns across Europe's footwear firms complicate the standard construct for which trade remedies were originally written. Anti-dumping rules assume a simple dichotomy between domestic and foreign producers: domestic firms file a complaint and are helped by import restrictions while foreign producers respond to the allegations and bear the burden of tariffs (along with domestic importers of the product). In a globalized economy with cross-national supply chains, this simple model breaks down. A 'domestic' firm with headquarters in the home country (often with highly paid employees) may outsource the product from a foreign manufacturing firm and then be subject to anti-dumping duties. This new commercial reality is not reflected in the formal requirements for assessing injury and dumping in the EU's anti-dumping law - but was dramatically evident in the politics behind the Footwear dispute, to which we now turn.

\subsection{The political background: the case that almost wasn't}

As noted above, the firms seeking anti-dumping duties were concentrated in a small number of EU countries, primarily in Italy, Spain, and Portugal, as well as - later on - in some newer EU member states, such as Poland, Slovakia, and Romania. On the other hand, the national footwear manufacturing associations based in the Netherlands, Belgium, the Scandinavian states, and the UK opposed the request, as many of their members had outsourced at least part of their production to China or elsewhere. Other powerful interests opposed the petition as well. For example, the Federation of the European Sporting Goods Industry (FESI), which represents many European-based multinationals that sell sports footwear, such as adidas, Nike, Puma, and Reebok, were dependent on production from China and opposed the imposition of duties. In addition, a number of large brands/marketers of high-quality dress shoes, such as ECCO, Timberland, Wolverine, Clarks, and Deichmann created ad hoc associations to lobby against duties on Chinese footwear. ${ }^{11}$

By February 2006, press reports stated that the Commission had found 'clearcut' evidence of dumping and would seek to impose duties. ${ }^{12}$ These reports sparked increased lobbying activities by national importer/retailer organizations from the UK, Sweden, the Netherlands, France, and Denmark as well as other industry groups. The strong opposition helped shape a March 2006 proposal that the Commission submitted to the EU's Anti-Dumping Committee (ADC) for a consultative vote. Members of the ADC were sharply divided. A small group of states - including Italy, Spain, and Portugal-criticized the proposal for seeking

11 For a fuller description of the role of industry groups in this area, see Eckhardt (2011), from which much of the analysis in this section is drawn.

12 See, e.g., The Guardian (2006). 
duties that were too low $(19.4 \%)$, and for excluding children's and 'specialtechnology athletic footwear' (STAF) sports shoes. A much larger group of EU members-including Sweden, Denmark, Finland, the Netherlands, and the UK - argued that no measures should be taken. The proposal attracted three votes in favor, 11 votes against, and 11 abstentions. ${ }^{13}$ Relevant EU rules consider abstentions as affirmative votes; thus, although the proposal attracted only three 'yes' votes, the overall result was 14 in favor (three yes votes plus 11 abstentions) and 11 against. The Commission then announced the imposition of provisional anti-dumping duties on imports of footwear from China, to last for a period of six months. ${ }^{14}$

Thereafter, EU bodies considered whether to impose duties on Chinese footwear at least four additional times. In July 2006, the Commission sought to find consensus through a compromise. Under this proposal, 140 million pairs of shoes would enter the EU without restriction; any subsequent imports would face duties of $23 \%$. Italy, Spain, France, Poland, and Portugal firmly opposed this compromise tariff-rate quota. In light of the disagreement among member states, a new meeting of the ADC was scheduled for 3 August. Prior to this meeting, the Commission submitted a new proposal that would impose tariffs of $16.5 \%$ on China, including on children's shoes. However, once again a majority of states refused to support the Commission's proposal, with 15 of 25 states casting 'no' votes. 15

Disagreement was so intense that the issue was finally raised to the ministerial level, which is very unusual for anti-dumping cases. The Commission, in turn, developed another compromise proposal; it would impose duties of $16.5 \%$ for just two years (instead of the usual five years) and exclude STAF footwear. The Council of (Trade) Ministers was scheduled to vote on this proposal on 5 October 2006 - the day before the provisional duties were scheduled to end.

All parties understood that the vote would be very close, and in the weeks prior to the Ministerial meeting, the arcane question of whether to impose duties on Chinese footwear moved to the center of European politics. Italian Prime Minister Prodi, Spanish Prime Minister Zapatero, and German Chancellor Merkel, among others, became personally involved. Press reports provide a hint of the nature and intensity of the lobbying on this issue. For example, Britain reportedly offered a secret deal to Italy that it would drop its opposition to duties if Italy would support UK efforts to receive an exemption from a proposed EU regulation limiting the workweek to 48 hours. ${ }^{16}$ Although this proposed deal apparently fell apart, other efforts to influence votes were more successful. One detailed analysis of the politics behind this dispute even goes so far as to suggest that Italy promised to vote against

13 See EU Observer (2006) and Financial Times (2006a).

$14 \mathrm{EU}$ (2006a).

15 See Euractiv (2006).

16 See Financial Times (2006b). 
Turkey's EU membership whenever that issue came to the Council in order to sway Cyprus to abstain. ${ }^{17}$

Ultimately, nine countries - France, Greece, Hungary, Italy, Lithuania, Poland, Portugal, Slovakia, and Spain-reportedly voted in favor of duties. Twelve countries-Belgium, Czech Republic, Denmark, Estonia, Finland, Germany, Ireland, Latvia, Luxembourg, Netherlands, Sweden, and UK - voted against. Four states - Austria, Cyprus, Malta, and Slovenia-abstained. ${ }^{18}$ Because the relevant EU procedural rules consider abstentions as equivalent to yes votes, the measure passed by a count of 13 to 12 .

In short, the effort to impose anti-dumping duties on Chinese footwear triggered significant rifts within the EU. As a result, the Commission was unable to craft a proposal that could capture majority support from the EU membership. Nevertheless, duties were imposed, by the slimmest of margins, because of a procedural rule that considers abstentions to be 'yes' votes. Absent this rule, it is not clear that any of the Commission's proposals to impose duties on Chinese footwear would have enjoyed sufficient support to lead to the imposition of duties. A safeguard action, which would have required a 'qualified voting majority' (essentially a population weighted majority), would have faced a much higher bar. Assuming that only Germany, Britain, the Netherlands, Austria, and Finland would have voted against a safeguard, the measure could receive, at most, only 247 of the requisite 255 votes.

\section{The Panel Report}

China challenged three EU measures: the ADR, the 2006 regulation imposing definitive anti-dumping duties on Chinese footwear, and the 2009 regulation extending these duties following an expiry review. China brought 'as such' and 'as applied' claims against the ADR, and challenged numerous aspects of the other two regulations. The lengthy panel report contains at least 46 separate findings.

The large number of claims raised by China renders infeasible a review of all issues here. Hence, we have selected three issues of particular interest: the panel's finding that the EU had impermissibly required NME producers to demonstrate that they are entitled to individual treatment; the panel's analysis of the EU's use of sampling in its investigation; and the EU's selection of Brazil as an analogue country.

\subsection{Requiring producers to demonstrate entitlement to individual margins}

The central doctrinal issue presented in this dispute is the WTO-consistency of the ADR's approach to individual treatment. China argued that the Anti-dumping Agreement (ADA) requires an anti-dumping margin and duty for all individual

17 See Eckhardt (2011), p. 983.

18 The votes are secret; this account is drawn from Eckhardt (2011). 
exporters, subject only to an exception when the number of producers involved renders this infeasible. The EU argued that given state control over trade in NMEs, exporting firms are not independent actors and collectively constitute a single supplier; a single countrywide duty thus prevents circumvention of anti-dumping measures by channeling exports through low-duty suppliers.

The panel found that this issue is governed by ADA Article 6.10:

6.10 The authorities shall, as a rule, determine an individual margin of dumping for each known exporter ... In cases where the number of exporters ... involved is so large as to make such a determination impracticable, the authorities may limit their examination ... to a reasonable number of interested parties or products by using samples...

6.10.2 In cases where the authorities have limited their examination ... they shall nevertheless determine an individual margin of dumping for any exporter ... who submits the necessary information ... except where the number of exporters ... is so large that individual examinations would be unduly burdensome.

The panel agreed with China that sampling was the sole exception to individual treatment authorized by ADA Article 6.10. Given this reading, it was impermissible for the EU to require Chinese producers to bear the burden of demonstrating that they were entitled to individual dumping margins. ${ }^{19}$

The panel found that the ADR's IT rules also violated ADA Article 9.2. This article provides that, when anti-dumping duties are imposed, ' $[\mathrm{t}]$ he authorities shall name the supplier or suppliers of the product concerned. If, however, several suppliers from the same country are involved, and it is impracticable to name all these suppliers, the authorities may name the supplying country concerned.' The panel stated that this provision 'further elaborates on the basic principle of individual treatment established in [ADA Article 6.10]', and hence reinforces the conclusion that individual exporters ... should be treated individually in the determination and imposition of anti-dumping duties'.

The panel's findings raise intriguing questions regarding allocation of the 'burden of proof' in the context of anti-dumping investigations involving NMEs. In general, investigating authorities have the burden of establishing that the conditions precedent to the imposition of $\mathrm{AD}$ duties (i.e., dumping, injury, causation) are satisfied. Notably, however, China's Accession Protocol suggests that, at least for some issues, it is appropriate to reverse the normal burden of proof. In particular, paragraph $15(\mathrm{a})(\mathrm{i})$ of the Protocol provides that if the producers under investigation can clearly show that market economy conditions prevail' then the importing state 'shall use Chinese prices' in determining normal value. If producers cannot 'clearly show' that market conditions prevail, then WTO members can use alternative methods, such as a surrogate third country.

19 EU-Footwear, para. 7.88 . 
The underlying policy question is whether, and when, it is appropriate to allocate the burden of proof to NME exporters. More specifically, if it is legally permissible to require Chinese producers to 'clearly show' market economy conditions prevail when calculating 'normal value', why is it inappropriate to require Chinese producers to show they are entitled to individual treatment when calculating the export price?

From a public policy perspective, allocation of the burden of proof should, in general, be designed to limit social costs associated with dispute settlement (including the costs of processing disputes and the costs of erroneous outcomes) to a reasonable level. Of course, this general principle can be devilishly difficult to operationalize in particular settings. Moreover, many courts have noted that, in addition to cost minimization, evidentiary burdens should reflect the underlying substantive policies of the law that is being invoked. In practice, no single principle is used to allocate burdens of proof; ${ }^{20}$ instead, it appears that several different factors are commonly assessed.

One widely used principle is that the party who seeks judicial remedy has the burden of producing evidence which is a prerequisite to such action. The standard justification for this approach is that it conserves legal resources by ensuring that the law's 'cumbrous and expensive machinery' is not put in motion unless it is shown to be warranted. ${ }^{21}$ Application of that principle here cuts against imposing an affirmative obligation upon Chinese producers to show entitlement to IT status. Chinese producers are not seeking action by EU authorities. Rather, the EU is seeking to determine whether imposing duties on Chinese producers under NME rules is justified; under this principle the burden should properly fall upon the EU to make this demonstration.

A second general principle cuts in the other direction. Burdens of proof often fall upon the party who has superior access to the evidence necessary to prove a particular fact. ${ }^{22}$ This approach has the virtue of reducing the overall costs of litigation. In Footwear, the Chinese firms are obviously much better placed than the Commission to adduce evidence on whether their operations are free of state interference. Shifting this burden to the EU, on the other hand, imposes a substantial administrative burden on the investigative authorities and could greatly increase both the costs and the length of investigations.

A final and oft-decisive factor is that the burden of proof should be allocated in ways that best further the substantive values advanced by the underlying law. This principle is particularly difficult to apply in the context of the ADA. Is the underlying value, in the words of GATT Article VI, that dumping is to be condemned if it causes ... material injury to an established industry' and that WTO

20 E.g., Wigmore (1981).

21 See Holmes (1881), p. 77.

22 See Thayer (1890), p. 59. 
members are authorized to impose anti-dumping duties against dumped products? If so, then it could be argued that allocation of the burden of proving entitlement to individual treatment to Chinese firms is appropriate, as this allocation would lead to higher duties against dumped goods, reducing the incentive to dump in the first place. But what if the underlying substantive value is, in the words of the ADA, that importing states can impose anti-dumping measures 'only under the circumstances provided for in Article VI of GATT 1994 and pursuant to investigations ... conducted in accordance with the [ADA]'? Given that these texts generally require individual treatment, then the burden should be on the EU to demonstrate that denial of individual treatment is consistent with the ADA. The panel's conclusions are consistent with this line of argument.

It is, however, unlikely that the panel's conclusion was motivated by its understanding of how to best advance the substantive values that underlie the ADA because there is 'a fundamental normative dissensus' regarding the purpose and justification of WTO anti-dumping rules (Howse and Neven, 2003). The lack of consensus over the substantive normativity of dumping-not to mention the dissensus over how anti-dumping rules should be applied in the context of NMEs - renders it virtually impossible to allocate burdens of proof in disputes like those at issue in Footwear in light of the substantive values advanced by the underlying law.

Although there might be a normative dissensus regarding the substantive values advanced by WTO anti-dumping rules, there is greater agreement over certain procedural values. This reality is reflected in the ADA's text, which includes many highly detailed provisions that are procedural in nature and seek to ensure a degree of transparency and procedural fairness. We believe that the values underlying these rules may suggest an alternative rationale that justifies the panel's decision. Consider the facts in this case. None of the Chinese producers that sought MET and IT was successful. ${ }^{23}$ Close examination of the record reveals that many of the firms' requests were rejected for failure to satisfy the burden of proof; in only a very few instances did the Commission reach a substantive determination on the merits. By way of example, of the 13 sampled firms that sought MET, one failed to return a questionnaire and its MET request was denied; four submitted information that was 'substantially incomplete and therefore no conclusions could be drawn as to whether they fulfilled the relevant criteria'; ${ }^{24}$ and the requests of other companies were rejected because they 'did not properly substantiate their allegations that they

23 More accurately, during the Commission's initial investigation, all firms were denied MET and IT. After imposition of provisional duties but before imposition of definitive duties, all of the Chinese producers selected in the sample argued that they had wrongly been denied MET status. One of these firms, Golden Step, provided evidence of a 'substantial change' and it was granted MET. The other firms were denied MET. Similarly, some of the Chinese firms selected in the sample argued that they had wrongly been denied IT. However, none of them provided any new evidence, and their claims were rejected.

$24 \mathrm{EU}$ (2006a), recital 71. 
obtained [certain] assets at market conditions' ${ }^{25}$ In general, many denials of MET (and of IT, which is based on much the same information) to Chinese firms in Footwear did not reflect a considered decision on the merits by EU officials; rather, in the absence of evidence the allocation of the burden of proof was dispositive.

What would happen if the burden of proof were reversed? Requiring the EU to show why IT is not appropriate would incentivize the EU to seek to apply NME rules to firms that truly operate in an NME context. As a loose analogy, consider the impact of placing high burdens of proof in criminal cases on prosecutors. The imposition of high burdens (e.g., 'proof beyond a reasonable doubt') makes it more difficult to convict, thereby incentivizing prosecutors to prosecute cases they are highly confident they can win (i.e., where there is very good reason to believe defendants are, in fact, guilty). Perhaps the Footwear panel decision can be understood as an effort to incentivize the EU not to apply NME rules in an undifferentiated or blunderbuss fashion, but only where doing so is truly warranted.

In this action, it appears that the evidence the EU relied upon in denying IT consisted of little more than the fact that the relevant firms were Chinese. The panel may properly have been skeptical that this quantum of evidence is sufficient. To be sure, it is possible (although unlikely) that the EU undertook an independent investigation on this issue and was unable to produce any other evidence that any of the relevant firms were under state control. In such circumstances, a panel might conclude that as a matter of law and policy the EU should not be entitled to invoke NME rules. On the other hand, it is much more likely that the EU undertook no affirmative, independent investigation into whether any particular Chinese firm was sufficiently independent of the state to justify IT. Given the due process and fairness concerns that run throughout the ADA, a panel might conclude that a WTO member is not entitled to disadvantage a foreign firm if it has not undertaken an investigation or produced evidence to justify such treatment.

\subsection{Product scope and sampling}

A critical aspect of any anti-dumping case is to establish the limits of what specific products are included in an investigation and the EU-Footwear case was no exception. The product line 'certain footwear with leather uppers' potentially can involve a very wide variety of products including, for example, women's dress shoes, men's athletic shoes, and children's sandals.

The importance of product scope in the investigation is multi-faceted. Import patterns (including import surges and import market share) relevant to injury determinations can depend greatly on the specific products included in the investigation; imports may be rising sharply for one type of shoe while showing only modest changes in another. Similarly, the situation for domestic firms in one

25 Ibid., recital 75 . 
part of an industry may be markedly different than in others: one segment may be buffeted by import competition, while another might face changing consumer demand or technical change. In the context of EU procedures, the definition of the product can also be very important in establishing the parameters of a 'Community interest' determination.

In addition, the product scope will determine which specific foreign producers are investigated and what prices will be considered when examining dumping margins and possible import restrictions. This in turn will determine which firms might be sampled during the investigation. As noted above, a domestic authority need not investigate each foreign firm if there are a sufficiently large number of exporters. In such cases, the authority only must investigate a sample of firms making the product under investigation.

The ADR defines 'like product' (using language essentially identical to the WTO Anti-dumping Agreement):

'[L]ike product' means a product which is identical, that is to say, alike in all respects, to the product under consideration, or in the absence of such a product, another product which, although not alike in all respects, has characteristics closely resembling those of the product under consideration. ${ }^{26}$

This formulation allows for considerable Commission discretion, which was a critical part of the original anti-dumping investigation. All footwear is similar, even 'identical' in many aspects - they protect feet, have soles, come in pairs, and have some sort of binding across the instep. They also vary according to their end-use, ranging from house slippers to hiking boots to high heels to construction boots.

In particular, 'leather shoes' is a very broad term and there was considerable disagreement among EU interested parties about the investigation's scope. In the notice of initiation, the scope included footwear with uppers but excluded products such as cycling shoes, ski boots, and boots with a protective toecap. ${ }^{27}$ These footwear types certainly seem distinctive from other footwear based on their end use (specialized boots for athletics and construction). There were subsequent disagreements over possible exclusion of 'special technology athletic footwear' (STAF), children's shoes, and various other types of shoes. The exclusion of STAF shoes, which include high-end running shoes with specialized soles, was very important to large multinational sports brands, such as Nike, adidas, Puma, and Asics.

In the end, the Commission ruled that the products in the investigation included essentially sandals, boots, 'urban' footwear, and 'city' shoes. ${ }^{28}$ STAF (with import prices greater than 9 Euros) would be excluded from anti-dumping duties while children's shoes would remain within the definition of the like product. 
As a practical matter, these choices about what products to exclude were a consequence of political wrangling and outside pressure from importers, retailers, and multinationals as detailed by Eckhardt (2011) rather than sound economic logic. The arguments put forward by the Commission for this particular group of products are unpersuasive from an economic point of view. The Commission argued that STAF were distributed through different sales and distribution channels than other covered products. The Commission also argued that STAF were 'perceived' by consumers as being distinct from other footwear and designed for specialized sporting activities. At the same time, children's leather sandals were considered a 'like' product with men's dress loafers. There is no substitutability between these products in end-use. At the same time, an adult male might wear either high-end sports shoes or leather sandals while shopping for groceries, which would suggest that men's 'town shoes' and STAF might conceivably be like products.

The decision about the scope of 'like products' also has important implications for which European Community firms would be examined for the presence of material injury. The ADR defines Community Industry as 'producers as a whole of the like products' but excludes producers that 'are related to the exporters or importers or are themselves importers of the allegedly dumped product'. ${ }^{29}$ The latter phrase means that the economic conditions of multinational firms like adidas and ECCO, who are in some sense part of the 'Community' footwear industry, were excluded from the injury investigation.

As noted above, the Panel rejected the EU policy to assume that every firm in China operates under non-market conditions unless the firm can prove otherwise. However, the Panel reaffirmed the ability of the Commission to use sampling. In essence, the Panel report will make questions about sampling even more important in the future than in the past.

The EU's procedures focused on the second option in Article 6.10, i.e. using sampling to select a group of firms that represent a 'large' percentage of exports and then use that for a weighted average for non-sampled firms.

The Panel provided broad discretion to authorities regarding how to select the exporters in a sample. The EU reported that 163 Chinese footwear firms identified themselves as exporters to the Community in the original investigation. The EU initially planned to sample only the four largest Chinese producers but, after consultations with Chinese authorities, expanded this to thirteen firms representing about $25 \%$ of covered product exports. ${ }^{30}$ China raised the issue of whether this was an appropriate sample in EU-Footwear in terms of basic fairness of administrative approaches. The Panel rejected that claim since the language of Article 6.10 requiring an investigation of 'the largest percentage of the volume 
of exports ... which can reasonably be investigated' does not also require that the sample be 'representative' of the industry as a whole. ${ }^{31}$ An economist or statistician might object to this result, arguing that a sample of the largest firms (either in a NME context or otherwise) may be unrepresentative and is inappropriate to apply to smaller exporters that likely have very different economic circumstances. ${ }^{32}$ But the language of the agreement seems to provide domestic authorities with the flexibility to continue to examine only large firms in dumping investigations. Ultimately, the language in Article 6.10 that allows authorities to use either a statistically representative sample or one that covers a large percentage of export remains in full effect.

The Panel could have weighed in on how the last part of the relevant text, i.e., what determines 'reasonableness' when assessing the investigation costs to domestic authorities. A Panel or Appellate Body may hesitate to examine the internal resource constraints of a domestic authority to determine whether it would be 'reasonable' to expect more investigations of individual firms. But simply accepting investigators' assertion that examination of more firms is too costly seems to provide too much deference. It is worth recalling that the Commission originally intended to investigate only four Chinese exporters before expanding it to thirteen. If they had simply said in the beginning that four was the maximum possible number of firms that could be investigated, this would surely have been inappropriate as they were in the end able to investigate more than three times that many.

Sampling is tightly linked to the product scope so important in EU-Footwear. The industry's decision to pursue an anti-dumping case instead of a safeguard action forced the Commission to investigate individual Chinese firms' pricing behavior. The broad scope of the covered products (sandals, dress shoes, and boots), with hundreds of Chinese firms (and hundreds of EU producers), increased the potential administrative burden on the Commission of examining evidence. The wide range of producers with heterogeneous costs increases the possibility that a limited firm sample could lead to 'unfair' outcomes. Ironically, the issue upon which the EU lost so decidedly ('individual treatment' of all Chinese exporters, at least in principle) could have been avoided if a different trade defense mechanism was chosen.

\subsection{Selection of the analogue country}

The ADR presumes that market forces do not drive prices in NMEs and are therefore not reliable for determining normal value. As a result, the EU typically selects a market economy country (the 'analogue' country), in which the price or constructed value of the like product will be assessed. However, the ADR provides

31 Ibid., para. 7.216.

32 See Broude and Moore (2013) for a more extensive elaboration of this point. 
little guidance on how to choose an analogue country, stating only that the selection be made in a 'not unreasonable manner' and that due account should be taken of reliable information available at the time of selection. In practice, the Commission's choice is strongly influenced by the volume of representative domestic sales in the analogue country compared to the exports of the product from the NME. Highly practical concerns are also extremely relevant, including the extent to which producers in potential analogue countries are willing to cooperate with the investigation.

In this action, the Commission used Brazil as the analogue country. Several interested parties objected on the grounds that Brazil is quite unlike China in terms of socio-economic development; has higher labor, research and development, and design costs; has significantly better access to leather (with one of the world's largest commercial bovine herds); uses higher quality leather than China; and applies very high import duties on shoe imports. These parties suggested that Thailand, India, or Indonesia would be more suitable than Brazil. The Commission rejected these suggestions, in part because there were limited domestic sales in these countries, and in part because of the limited number of producers in these nations willing to cooperate with the investigation. Moreover, the Commission noted that neither the difference in economic development, nor in the costs of the production structures, rendered Brazil necessarily inappropriate as an analogue country.

In Footwear, China argued that EU procedures in selecting an analogue country, and the selection of Brazil as the analogue country in particular, violated ADA Articles 2.1 and 2.4. It appears that this was the first time that questions regarding selection of an analogue country in an NME anti-dumping investigation had been litigated in a WTO dispute. Hence, the panel's treatment of this issue is of considerable interest.

The panel found that, as a definitional provision, ADA Article 2.1 creates no obligations with respect to selection of the analogue country. ${ }^{33}$ Article 2.4 provides that '[a] fair comparison shall be made between the export price and the normal value'. China argued that this sentence created an 'independent' and 'overarching' obligation that covered all aspects of the determination of normal value, including the selection of the appropriate analogue country. The panel rejected this claim. It reasoned that, on its face, Article 2.4 addresses the 'comparison' between the export price and normal value. But nothing in Article 2.4 speaks to the determination of the component parts of the comparison to be made, i.e., normal value and export price. Indeed, the requirement to make a fair comparison 'logically presupposes that normal value and export price, the elements to be compared, have already been established'. ${ }^{34}$ The panel concluded that Article 2.4, either alone or in combination with Article 2.1, does not 'establish 
a general requirement of "fairness" which applies ... to the selection of an analogue country'.

The panel's confirmation that investigating authorities have substantial discretion in selecting an analogue country is potentially troublesome given its importance in determining dumping margins. Anti-dumping scholars and practitioners have long voiced concerns that the selection of the analogue country can be manipulated to produce inflated normal value determinations, in turn leading to inflated dumping margins. The selection of Brazil in this dispute underscores these concerns. While China has a higher GDP than Brazil, in many ways Brazil is a richer state at a different stage of economic development. Brazil's GDP per capita in 2008-12 was $\$ 12,584$, more than double China's GDP per capita of $\$ 5,445.35$ Energy costs in Brazil are significantly higher than in China. A comprehensive study of the costs of doing international business found that while China is a low-cost leader among high growth countries, the cost of doing business in Brazil is similar to that of mature economies such as the US. ${ }^{36}$

Footwear is hardly the only time that the EU selected an analogue country that is at a different stage of economic development than the respondent country. In antidumping investigations involving NMEs between 2005 and 2010, the EU most frequently selected as analogue countries the US and Turkey; together they were selected in $60 \%$ of NME cases over this period. Additional data on the choice of analogue countries can be found in Figure 4.

EU analogue country selection practices raise several concerns. As a practical matter it is understandable that the Commission gives substantial weight to the willingness of producers in specific countries to cooperate with the investigation particularly given that third country producers have no obligation to cooperate. Nevertheless, the reliance on the willingness of firms in third countries to cooperate is potentially problematic. Firms in third states will readily understand that they may benefit from duties imposed on NME producers, so there is some risk that companies with higher costs (and hence higher normal values) will be more willing to cooperate, knowing that this is likely to lead to higher dumping margins on Chinese exporters. This produces the potential for inflated dumping margins.

The lack of predictability is also problematic. NME producers who wish to avoid the imposition of anti-dumping duties have no way of knowing the basis of the dumping margin calculation. For this reason, the use of an analogue country to determine normal value has been described as the 'trade policy equivalent of charging a driver with speeding on a road with no posted limits, based upon the limits posted on some other road - a road that will be chosen after the driver has been stopped' (Palmeter, 2003).

35 See World Bank Database, available at http://data.worldbank.org/indicator/NY.GDP.PCAP.CD/ countries.

36 See, e.g., KPMG (2012). 
Figure 4. Analogue countries in EU anti-dumping investigations, 2005-2010

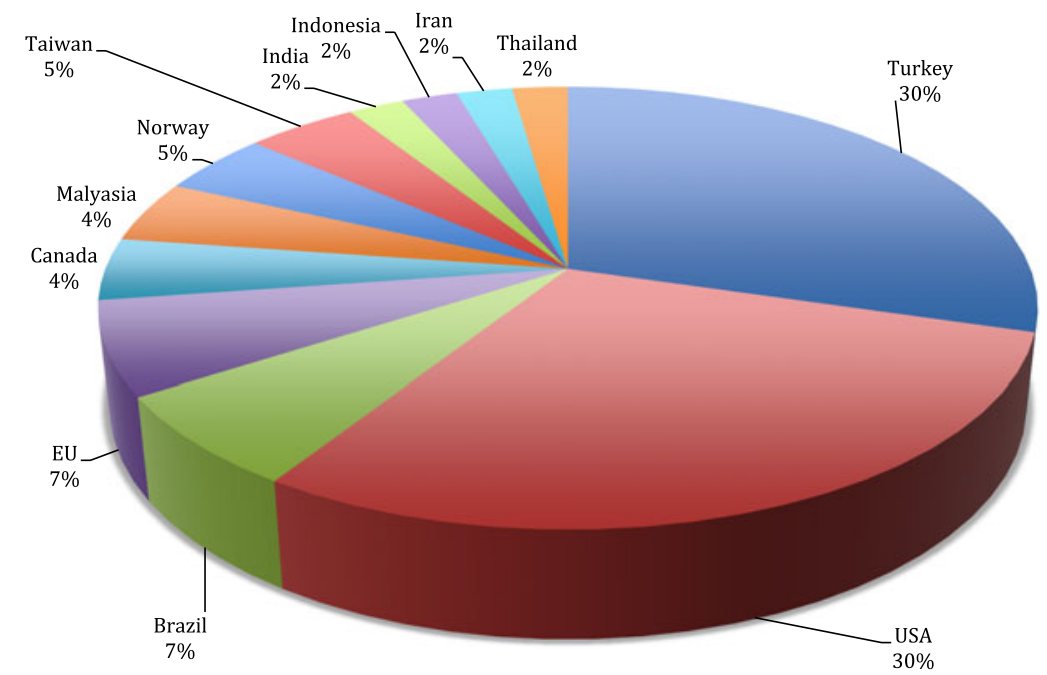

Source: Adapted from BKP (2012).

It is reasonable to assume that the Footwear panel was aware of the potential for manipulation in the selection of an analogue country. But the panel was not free to impose its own views of sound anti-dumping policy, or to rewrite the ADA text. The panel's finding that the EU's selection of Brazil as the analogue country in this case violated no obligations found in either ADA Article 2.1 or 2.4 rests on entirely plausible readings of the relevant texts, which neither mention the term 'analogue country' nor address the procedure nor criteria for the selection of an analogue country. Moreover, the panel's findings are entirely consistent with the views of the majority of states who opined on this issue. The panel's rather terse treatment of this issue may serve to discourage future litigation over the criteria and procedures for selecting analogue countries, and to highlight the discretion that investigating authorities have in conducting anti-dumping investigations.

\section{Observations and implications}

We now examine some of the dispute's larger implications. We do so, first, from the perspective of firms in the importing state, who decide between pursuit of different trade remedies. We then examine the benefits to importing states of imposing antidumping duties; and, finally, the benefits to exporting states of challenging the imposition of anti-dumping duties.

\subsection{Safeguards $v$. anti-dumping}

In many respects, changing patterns of competitive advantage in the footwear industry suggest that a safeguard action would have been more appropriate than 
anti-dumping duties. However, the differing legal requirements for safeguard measures and anti-dumping duties incentivize firms to seek the latter. As detailed in Table 4, EU safeguard rules require more political support (qualified rather than simple majority in the Council of Ministers), necessitate a member nation or the Commission to initiate the investigation (rather than the domestic industry), may require compensation (if the global safeguard lasts the same five years that is typically the case with anti-dumping orders), require serious injury (rather than material injury), and are accompanied with the expectation of industry restructuring (that is absent in anti-dumping actions). Finally, global safeguards impose restrictions on all imports sources so that a much wider range of exporting nations might be affected compared to an anti-dumping order. In the case of Chinese exports, domestic firms could choose to pursue (at least until 2014) a China-specific safeguard. This import restriction had the same injury standard as anti-dumping ('material injury'), did not involve any expectations for industry restructuring as with global safeguards, and compensation was not expected (similar to antidumping). However, a China-specific safeguard did require the same level of political support in the EU as a global safeguard ('qualified majority'), a higher standard than that required to impose anti-dumping duties ('simple majority').

As a result, EU industries have been far more likely to pursue anti-dumping cases (Table 4). Since 1995, there have been 433 anti-dumping cases initiated in the EU, five global safeguards, and only one China-specific safeguard, which, however, was not used as a legal basis to impose a safeguard measure. ${ }^{37}$

The EU footwear industry in principle is exactly the kind of sector that negotiators had in mind when developing the safeguard system. In particular, the industry is being buffeted by changing comparative advantage as developing countries become fearsome global competitors in this relatively labor intensive production sector. However, there are particular advantages of anti-dumping over the two types of safeguard action for the footwear industry. As a doctrinal matter, a series of Appellate Body decisions on safeguards removes much of the incentive to pursue global safeguard actions. In particular, the AB's interpretation that a safeguard is only allowed if there are 'unforeseen developments' essentially precludes its use against Chinese footwear exports; the removal of quotas on Chinese footwear exports was almost certain to put significant pressure on domestically based European firms. The China-specific safeguard superficially would seem to be an attractive option as well, as it is designed precisely to deal with surges of Chinese imports during the phase-in period after Chinese WTO accession. Unfortunately for the industry, Viet Nam is an important potential source of

37 Bown (2012). Note that an anti-dumping case involving two countries and a single product (e.g. stainless steel fasteners) and two countries (e.g. India and Malaysia) are considered as one initiation in these statistics. Global safeguards by their nature involve all import sources. 
footwear imports so that the China safeguard might not be as effective. Using antidumping allowed the industry to target both China and Vietnam.

As a political matter, anti-dumping is a more technocratic option for the industry while safeguards require decisions of a more political nature. Anti-dumping requires highly technical calculations about 'normal value', the choice of analogue country with NMEs, how to account for exchange rates, etc. Safeguards are more transparently 'protectionist'; domestic firms do not claim 'unfair' pricing but instead only that they need 'breathing room' against foreign competition. But safeguards also require greater levels of political support. In the EU, this starts at the initiation stage where the Commission or a member state has to start the investigation. And it continues to the final phase where a qualified voting majority must support the decision to impose a safeguard. In short, the political costs of successfully pursuing a safeguard action would have been significantly higher than the cost of efforts to marshal support for anti-dumping. Of course, the decision to pursue anti-dumping duties imposed costs of its own. The political backlash sparked by this decision resulted in anti-dumping duties of much more limited duration than usual as well as a loss on key issues in a WTO dispute.

What were the benefits of the duties to the EU footwear industry? One frequent problem with import relief actions on specific countries is that they can result in a diversion of imports from the targeted nations to other suppliers. A clear example of this occurred in the China tire safeguard action analyzed by Charnovitz and Hoekman (2013). In that case, the US imposed safeguard measures on Chinese tires for passenger vehicles in 2009. In the end, Chinese products were simply replaced by other low priced sources of tires, with an estimated 1,000 jobs 'saved' in the US In essence, the safeguard, the use of which was deemed consistent with WTO obligations in a 2011 Appellate Body report, produced few benefits for the US industry.

The footwear industry presents a very different situation. Import restrictions on China and Vietnam could have major effects since they represent such a large fraction of world exports. Chinese passenger tire exports were $9.7 \%$ of world exports the year that the US imposed the China-specific safeguard. In sharp contrast, Chinese and Vietnamese share of world footwear (of all types in HS category 6403) trade was 33.7 and $4.9 \%$, respectively. ${ }^{38}$ This means that the ability of EU retailers and importers to find alternatives to these two countries was much more limited than in the tire example. Of course, this reality resulted in EU interests opposing the measures having a much stronger incentive to limit the scope, length, and general effectiveness of the restrictions.

Even if import restrictions had been long-lasting and effective, the basic economic realities are such that the pressures on small EU firms would continue unabated. The long-term pressures for rationalizing footwear production in Italy,

38 Compiled by the authors with data from UN Comtrade (http://comtrade.un.org/db/). 
Spain, Portugal, and other nations will be unrelenting. Smaller firms will be buffeted by changing styles of more casual and less expensive shoes. Higher unit labor costs will also push larger firms that can to offshore more and more production. What will likely will remain of the EU footwear industry in ten years will be even more niche producers making high-end shoes for a much smaller consumer base.

\subsection{The utility of challenging AD measures}

The direct commercial benefits to China of challenging the EU's footwear duties may have been limited. In fact, the EU's duties expired in April 2011, months before the panel report was circulated in October 2011. So, at least from the perspective of relevant market actors, the dispute over footwear had already become moot well before the report's release.

However, one of China's key objectives in filing this action was to exert pressure on the EU to permit the footwear duties to expire in 2011, without engaging in another expiry review and potential extension of the order. ${ }^{39}$ This objective was achieved. Instead of initiating another divisive debate among EU members on extending duties, EU officials decided to let the duties expire, and to monitor Chinese shoe imports for evidence of improper subsidization or intellectual property violations. So in this sense the China's litigation efforts achieved a key objective.

As a doctrinal matter, Footwear represents an unambiguous legal victory against a key element of the EU's NME regulations. Following the AB's report in Fasteners, which raised legal issues substantially similar to those raised by Footwear, the EU acknowledged that the ADR 'establishes a presumption that exporting producers operating in nonmarket economy countries are not entitled to IT' and that the AB found that 'no legal basis for such a presumption is provided for in the relevant WTO agreements'. However the EU emphasized that the AB permitted the determination of a single dumping margin and a single anti-dumping duty for a number of producers when those producers, albeit legally distinct, have structural links or other forms of common control that justify treating them as a single entity. The EU amended its Basic Regulation by essentially transposing the AB's language on when it is appropriate to treat legally distinct firms as a single entity subject to a single duty rate. Thus, while the Fasteners and Footwear reports delegitimate one legal strategy used to avoid the calculation and imposition of individual duties, the EU's response was to codify a different legal strategy that can be used to achieve precisely this result. That said, it appears that, to date, the EU has not utilized this new strategy when conducting anti-dumping investigations of firms in NME states.

39 We are grateful to Edwin Vermulist for emphasizing this point. 


\section{Conclusions}

The EU-Footwear dispute raises questions whether current global anti-dumping rules, and trade remedy laws generally, are well designed to operate in a world of globalized supply chains and off-shoring. WTO anti-dumping rules presuppose a world of vertically integrated firms where products are 'made' in country A, and where those firms compete with firms who produce in country B.

In today's global manufacturing economy, as the WTO constantly advises us, goods are 'made in the world'. The EU system of evaluating dumping and material injury is poorly designed for this type of world. For example, large multinational firms like adidas provide good jobs and high value-added in their slimmed-down European footwear operations. They do not fit well into the anti-dumping apparatus as they are considered 'importers' so that their economic interests only come into play in the final stages when the Council of Ministers consider 'Community interest'.

Hence, the conventional wisdom of political economy, that import-competing firms can overcome collective action problems in a way that consumers and others can not and drive protectionist policies, is no longer a fully accurate description of trade politics - as vividly illustrated by the internal EU splits in this case. AD duties are likely to harm those EU firms that are most integrated into the world economy, and provide only temporary and, at best, only limited relief to EU firms that produce exclusively for European consumers.

Finally, the dispute highlights China's recent turn to a more aggressive stance in WTO dispute resolution. The claims made by China in EU-Footwear were broad and numerous. While the Panel rejected the vast majority of specific complaints, the Chinese approach likely foreshadows similar aggressive arguments in future WTO trade disputes.

\section{References}

adidas Group (2012), Pushing Boundaries: adidas Group Annual Report 2012, available at http://www. adidas-group.com/en/investorrelations/assets/pdf/annual_reports/2012/GB_2012_En.pdf.

BKP Development Research and Consulting (2012), 'Evaluation of the European Union's Trade Defence Instruments', Contract No. SI2.581682.

Bown, C. P. (2012), 'Global Antidumping Database', available at http://econ.worldbank.org/ttbd/gad/.

Broude, T. and M. Moore (2013), 'US - Anti-Dumping Measures on Certain Shrimp from Viet Nam: A Stir-Fry of Seafood, Statistics, and Lacunae', World Trade Review, 12(2): 433-462.

Charnovitz, S. and B. Hoekman (2013), 'US-Tyres: Upholding a WTO Accession Contract-Imposing Pain for Little Gain', World Trade Review, 12(2): 273-296.

Eckhardt, J. (2011), 'Firm Lobbying and EU Trade Policymaking: Reflections on the Anti-Dumping Case against Chinese and Vietnamese Shoes (2005-2011)', Journal of World Trade, 45(5): 965-991.

Euractiv (2006), 'EU Governments Divided over Duties on Asian Shoes', last modified 31 August 2006, available at http://www.euractiv.com/trade/eu-governments-divided-duties-as-news-216975.

European Union (EU) (2005), 'Commission Notice (EC) No. 2005/C 166/06: Notice of Initiation of an Anti-dumping Proceeding Concerning Imports of Certain Footwear with Uppers of Leather 
Originating in the People's Republic of China and Vietnam', Official Journal of the European Union, C 166/14, 7 July.

- (2006a), 'Commission Regulation (EC) No. 553/2006: Imposing a Provisional Anti-dumping Duty on Imports of Certain Footwear with Uppers of Leather Originating in the People's Republic of China and Vietnam', Official Journal of the European Union, L 98/3, 23 March.

— (2006b), 'Council Regulation (EC) No. 1472/2006: Imposing a Definitive Anti-dumping Duty and Collecting Definitively the Provisional Duty Imposed on Imports of Certain Footwear with Uppers of Leather Originating in the People's Republic of China and Vietnam', Official Journal of the European Union, L 275/1, 5 October.

European Union (EU) (2009), 'Council Regulation (EC) No. 1225/2009: On Protection Against Dumped Imports from Countries Not Members of the European Community', Official Journal of the European Union, L 343/51, 30 November.

EU Observer (2006), 'EU States Split Over Anti-dumping Duties on Shoes', 17 March 2006, available at http://euobserver.com/?aid=21156 (last visited 7 May 2013).

Financial Times (2006a), 'EU Curbs on Shoe Imports Attract Only Three Votes', 17 March 2006.

— (2006b), 'UK in Secret Deal with Italy on China Trade', 22 September 2006, available at http://www. ft.com/intl/cms/s/0/7d6ff982-4a7e-11db-8738-0000779e2340.html\#axzz2Zsb0gT43.

Helpman, E., M. J. Melitz, and S. R. Yeaple (2004), 'Export versus FDI with Heterogeneous Firms', American Economic Review, 94(1): 300-316.

Holmes, O. W. (1881), The Common Law, Boston: Little, Brown \& Company.

Howse, R. L. and D. J. Neven (2003), 'Argentina-Ceramic Tiles', in H. Horn and P. C. Mavroidis (eds.), The American Law Institute Reporters' Studies on WTO Case Law: Legal and Economic Analysis, New York: Cambridge University Press, pp. 168-182.

KPMG (2012), Competitiveness Alternatives: KPMG's Guide to International Business Location Costs: 2012 edn, available at http://www.competitivealternatives.com/reports/2012_compalt_ report_vol1_en.pdf.

Melitz, M. J. (2003), 'The Impact of Trade on Intra-Industry Reallocations and Aggregate Industry Productivity', Econometrica, 71(6): 1695-1725.

Palmeter, D. (2003), 'The Capture of the Antidumping Law', in The WTO as a Legal System: Essays in International Trade Law and Policy, London: Cameron May, pp. 13-30.

Thayer, J. B. (1890), 'The Burden of Proof', Harvard Law Review, 4(2): 45-70.

The Guardian (2006), 'Chinese Shoes Draw Mandelson into New Tariff Tussle', 19 February.

Wigmore, J. H. (1981), Evidence in Trials at Common Law, Vol. 9, sec. 2486, Revised by James H. Chadbourn, Boston: Little, Brown \& Company. 